\title{
Student-Teachers' Competence and Attitude towards Information and Communication Technology: A Case Study in a Nigerian University
}

\author{
Mudasiru O. Yusuf \\ Modupe R. Balogun \\ University of llorin, Nigeria
}

\begin{abstract}
The importance of ICT in empowering teachers and learners, and enhancing teaching and students' achievement has been highlighted in several studies. Similarly, the digital divide between the developed and developing nations had been of a serious concern to educators. The paucity of studies on ICT integration in the developing nations needs to be addressed so as to ensure total integration of ICT in the school curriculum. This study examined empirically student-teachers' competence and attitude towards information and communication technology. Gender influence on their competence and attitude were also examined. Participants were 382 student-teachers $(181$ males and 201 females) from the Faculty of Education, University of Ilorin, Nigeria. The data collected through a questionnaire were analysed using percentages, means, and chi-square statistics. Findings revealed that majority of the student-teachers have positive attitude towards the use of ICT and they are competent in the use of few basic ICT tools. Overall, no significant difference was established between male and female student-teachers' attitudes and use of ICT. The implication is that the student-teachers lacked the necessary competence in the full integration of ICT in the curriculum. This underscores the need to improve the ICT contents of teacher education programs in universities in developing nations.
\end{abstract}

Keyword: Student-teachers; ICT Competence; Attitude towards ICT; Teacher education

\section{Introduction}

The potentials of information and communication technology (ICT) to facilitate students' learning, improve teaching and enhance institutional administration had been established in literature (Kazu \& Yavulzalp, 2008; Kirschner \& Woperies, 2003). The use of information and communication technology as a tool for enhancing students' learning, teachers' instruction, and as catalyst for improving access to quality education in formal and non-formal settings has become a necessity. Recognising the impact of new technologies on the workplace and everyday life, teacher education institutions try to restructure their education programmes and classroom facilities, in order to husband the potentials of ICT in improving the content of teacher education. Information and communication technology as tools within the school environment include use for school administration and management, teaching and learning of ICT related skills for enhancing the presentation of classroom work, teaching/learning repetitive tasks, teaching/learning intellectual, thinking and problem solving skills, stimulating creativity and imagination; for research by teachers and students, and as communication tool 
by teachers and students (Collis \& Moonen, 2001; Derbyshire, 2003; Moursund \& Bielefeldt, 1999).

Information and communications technologies are computer based tools used by people to work with information and communication processing needs of an organization. Its purview covers computer hardware and software, the network, and other digital devices like video, audio, camera, and so on, which convert information (text, sound, motion, etc,) into digital form (Moursund \& Bielefeldt, 1999). Successful integration of ICT in the school system depends largely on the competence and on the attitude of teachers towards the role of modern technologies in teaching and learning. Thus, experienced teachers, newly qualified, and student-teachers need to be confident in using ICT effectively in their teaching (Kyriakidou, Chrisostomou, \& Bank, 2000).

Simply having ICT in schools will not guarantee their effective use. Regardless of the quantity and quality of technology placed in classrooms, the key to how those tools are used is the teacher; therefore teachers must have the competence and the right attitude towards technology (Kadel, 2005). Attitudes refer to one's positive or negative judgment about a concrete subject. Attitudes are determined by the analysis of the information regarding the result of an action and by the positive or negative evaluation of these results (Ajzen \& Fishbein, 1980). There is a common saying that attitude determines altitude. Studies have established close links and affinities between teachers' attitude and their use of ICT. More positive attitudes towards the computer were associated with a higher level of computer experience (Dyck \& Smither, 1995; Teo, 2008). Students' confidence on ICT can be explained through the attitude and behaviors of their teachers. Teachers' behavior is a critical influence on students' confidence and attitude towards ICT as they provide important role model to their students (Derbyshire, 2003). The literature suggests that lack of adequate training and experience is one of the main reasons why teachers do not use technology in their teaching. This also eventuates in teachers' negative attitude towards computer and technology. In addition, lack of confidence leads to reluctance to use computers by the teachers (Kumar \& Kumar, 2003). Attitude of pre-service and in-service teachers towards computer and technology skills can be improved by integrating technology into teacher education (Zammit, 1992). Findings have revealed that a significant relationship exist between computer attitude and its use in institutions for pre-service teachers (Khine, 2001), and also for serving teachers in the affective attitude, general usefulness, behavioral control, and pedagogical use (Yuen \& Ma, 2002). Attitude is a major predictor of future computer use. Lee (1997) study indicated the importance of appropriate responses to the trainee's feelings about using ICT as one of the factors critical to success. Thus, there is the need to take care of the emotional needs of student teachers as attitude is a major predictor of future ICT use. Student teachers have positive attitude and are highly enthusiastic about interactive whiteboards as an important feature of teaching and learning, and this motivated them to practice using the technology (Kennewell, \& Morgan, 2003)

Gender gap exists in education in sub-Saharan Africa, and out-of-school children, more of whom are girls, are deprived of any opportunity to gain ICT related knowledge and skills in school. African women have the lowest enrolment rates in the world in science and technology education at all levels. A study conducted in four African countries identified that while in principles girls are given the same opportunity as boys of access to computer, gender equity does not exist in practice (Derbyshire, 2003). However, Kirkpatrick and Cuban (1998) review had established that when female and male students had the same amounts and types of 
experiences of computer, females' achievement scores and attitudes are similar to that of male's at all educational levels.

Studies had established that females tend to be less interested in computer and use them less often in their spare time (Schaumburg, 2001). In addition, studies have established that girls are less confident than boys in their computer skills, and that some international studies have found that boys scored better than girls in computer related knowledge and skills in vast majority of countries. In addition, the three computer related occupation (computer scientists, computer engineers and system analysts, and computer science and engineering) are the top career choices for boys (Derbyshire, 2003). Female also have more negative attitude towards computer (Bebetsos \& Antoniou, 2008), thus they are often less computer literate than males (Kadel, 2005; Schaumburg, 2001; Townsend, 1997), thus they are often less computer literate than males (Schaumburg, 2001) and this may result in different ways of using the computer (Jackson, Ervin, Gardner, \& Schmitt, 2001). Sefyrin (2005) study showed that competence in ICT could be seen as a question of interest in ICT, where men are more interested in ICT than women. The study thus confirmed the view of gender and competence as actively constructed in a social process. This is because understandings of the terms were negotiated among individuals in the groups studied, and therefore used as norms with which individuals understood themselves and their behaviours.

Serving and student-teachers need to be skilled in the use of ICT and also to be able to critically evaluate strategies for the acquisition and the appropriate application of ICT in diverse curriculum area (Robbin, 1998). Major ICT competencies required by teachers were highlighted by Kirschner and Woperies (2003) to include competency in making personal use of ICT; mastery of a range of educational paradigms that make use of ICT; competency in making use of ICT as mindstools; competency in using ICT as tool for teaching, competency in mastering a range of assessment paradigms which involves use of ICT; and competency in understanding the policy dimensions of the use of ICT for teaching and learning. Pre-service teacher education should focus on the need for student-teachers to have ICT skills for their own use in the preparation of materials for teaching and learning activities; the need to facilitate the direct use of ICT in students' learning activities within the classroom situation; and the need for teachers to develop in their students a critical awareness of ICT applications and the social implications (Robbins, 1998). Similarly, Marija and Palmira (2007) classified ICT competencies into two: basic and educational ICT competence. These competences are further elaborated in the ICT competency standards for teachers developed by the United Nations Educational, Scientific and Cultural Organization (UNESCO, 2008a, 2008b). Based on these documents, the information and communication technology competency is comprehensive than mere focus on ICT skills. Rather, it is a comprehensive approach to education reform in six broad areas of policy, curriculum and assessment, pedagogy, the use of technology, school organization and administration, and teacher professional development. The UNESCO (2008a, 2008b) standards for teachers are meant to improve teachers' practice in using ICT in an innovative way for teaching, collaborating with colleagues, and for school organization.

Lee (1997) found that a great number of pre-service teachers are not equipped with basic computer operational skills; therefore, for teachers to be able to integrate ICT into the school curriculum, groundwork must be done at the pre-service teacher education level. Teacher educators need to understand the dimensions of pre-service teacher attitude as a means of developing teacher education curriculum relevant for the contemporary knowledge age. 
Studies have revealed that there is a wide gap between policy development and implementation in the Nigerian schools as regards computer education in Nigerian schools (Jegede \& Owolabi, 2005). Examining information and communication technology in the Nigerian health sector, only mobile phone and the Internet, to some extent, are available in the Nigerian hospitals (Idowu, Ogunbodede, \& Idowu, 2003). On teachers' competence, teachers in Nigerian secondary schools are not competent in basic computer operation and in the use of generic software (Yusuf, 2005), although they have positive attitude towards the use of computer in Nigerian secondary schools (Yusuf, 1998). These findings have revealed the low level of ICT penetration in the Nigerian school system, although the attitudes of teachers have been positive. These studies conducted on computer and ICT have focused mainly on practicing teachers in Nigerian secondary schools to the detriment of research on pre-service teachers. Most studies that examined the attitude of pre-service teachers towards ICT were conducted outside Nigeria; in fact, very few studies on attitude and competence in the use of computers have focused on the academic and non-academic staff of Nigerian higher institutions (Jegede, 2008, Ololube, 2007). Gaining an appreciation of student-teachers' attitude and perceived competence in the use of ICT may provide useful insight into the future of technology integration, acceptance and usage in teaching and learning in Nigerian teacher education institutions and other developing countries.

The main purpose of this study was to investigate the competence and attitude of student teachers towards information and communication technology. Specifically, the present study examined:

1. The attitude of student-teachers towards the use of ICT.

2. The competence of student-teachers in the use of ICT.

3. The influence of gender on student teachers' competence and attitude towards ICT.

The following research questions guided the study:

1. What is the attitude of student-teachers towards information and communication technology (ICT)?

2. What is the level of competence of student-teachers in the use of information and communication technology (ICT)?

3. Will there be difference between the attitude of male and that of female studentteachers towards information and communication technology?

4. Will there be differences in competence in the use of information and communication technology (ICT) between male and female student-teachers'?

Based on the research questions the following hypotheses were derived:

$\mathrm{Ho}_{1}$ : There is no significant difference between the attitude of male and that of female student-teachers towards information and communication technology (ICT). 
$\mathrm{HO}_{2}$ There is no significant difference between the competence of male and that of female student-teachers in the use of information and communication technology ICT).

\section{Methodology}

\section{Sample}

The participants were 382 student-teachers randomly sampled from the five departments of the Faculty of Education, University of Ilorin, Ilorin, Kwara State, Nigeria. The students were undergraduate student-teachers enrolled in the concurrent teacher education programmes for secondary school subjects, that is, B. A, (Ed.) or B.Sc. (Ed.) (Economics, English Language, Health Education, Mathematics, etc.), and education service disciplines B. Ed. (Counsellor Education, Educational Management, and Educational Technology). The student-teachers were stratified into male and female.

\section{Survey Instrument}

The survey instrument used for this research was developed by the researchers based on established procedures in literature. The survey instrument contained four sections. Section A included four questions and it focused on demographic information of student-teachers: department, course, level, and gender. Section B focused on student-teachers' attitude towards Information and Communication Technology (ICT). The section contained 14 items and the Likert response mode of Strongly Agree (SA), Agree (A), Disagree (D) and Strongly Disagree (SD) were used. Section $C$ of the questionnaire which contained two items addressed the issue of where student-teachers acquired their ICT knowledge and skills, while Section D was designed to know the level of competence of students-teachers in the use of ICT, specifically, basic ICT competence and not the educational ICT competence. The section contained 35 items and the response modes were: "I am fully competent with this application/operation" (FC coded 4); "I am a regular and confident user of this application" (RCU coded 3); "I have used this occasionally but need further training" (OU coded 2); "I do not use" (DU coded 1); and "I am not aware of this application/operation" (NA coded 0).

To test the instrument's validity and reliability, the initial draft was administered on 50 student-teachers drawn from a university in South West Nigeria. The feedback obtained from this first administration was used to revise the final instrument. The final instrument was tested for reliability using test-retest method of three weeks interval. The reliability coefficients obtained for the five sections of the instruments were 0.76 (attitude), 0.86 (Basic Computer Operation and Issues), 0.81 (Use of Application Software), 0.80 (Use of the Internet Resources), and 0.76 (Use of Peripheral ICT Equipment). Five hundred copies of the questionnaire were distributed to randomly selected student-teachers before lecture periods. The questionnaire was administered on the sample during the second semester of the $2007 / 2008$ academic session (February - May, 2008). Four hundred and seven copies were returned, out of which 25 were discarded due to incomplete data, thus 382 were found usable, at a return and usable rate of $76.40 \%$.

The responses for the respondents were tabulated and compared, and descriptive analysis (percentages and means) were done to present the details about the attitude and competence 
of student-teachers in the use of ICT. Furthermore, Chi-square statistics was used to test the two hypotheses generated in the study.

\section{Results}

The demographic information of the participants is given in Table 1. The table indicates that $47.38 \%$ were male students while female students were $52.62 \%$; this shows that both male and female students were fairly represented. With regard to departmental representation the table shows that Art and Social Sciences Education (ASSE) has $26.70 \%$, Counsellor Education (CED) has 9.69\%, Educational Management (EDM) has 21.99\%, Human Kinetics and Health Education (HKHE) has $14.14 \%$, while Science Education (SED) has $27.59 \%$, of respondents, respectively; this indicates that all departments were fairly represented.

Table 1.Demographic Information of Participants

\begin{tabular}{llll}
\hline Variables & & $\mathrm{N}$ & $\%$ \\
\hline Gender & Male & 181 & 47.38 \\
& Female & 201 & 52.62 \\
\hline \multirow{5}{*}{ Departments } & ASSE & 102 & 26.70 \\
& CED & 37 & 9.69 \\
& EDM & 84 & 21.99 \\
& HKHE & 54 & 14.14 \\
& SED & 105 & 27.49 \\
\hline
\end{tabular}

\section{Research Question One: What is the attitude of student-teachers towards information and communication technology (ICT)?}

The analysis related to this question is as shown on Table 2.

Table 2. Analysis of Results on the Attitude of Respondents towards the Use of ICT

\begin{tabular}{llllll}
\hline S/N & Items & SA & A & I & SD \\
\hline 1 & ICT enhances students' learning. & $276(72.25)$ & $104(27.23)$ & $(0.26)$ & $1(0.26)$ \\
2 & Teacher education should include ICT & $205(53.66)$ & $173(45.29)$ & $(0.79)$ & $1(0.26)$ \\
3 & Mail creates more information between & $151(39.53)$ & $189(49.48)$ & $6(9.42)$ & $6(1.70)$ \\
& teachers and learners. & & & & \\
4 & ICT provides better learning experiences. & $212(55.50)$ & $159(41.62)$ & $(1.70)$ & $5(1.31)$ \\
5 & I would work harder if I could use ICT. & $150(39.27)$ & $178(46.60)$ & $5(11.78)$ & $9(2.36)$ \\
6 & I learn more from ICT than I do from books. & $137(35.86)$ & $168(43.99)$ & $4(16.75)$ & $13(3.40)$ \\
7 & ICT is useful in dissemination of information. & $184(48.17)$ & $172(45.03)$ & $2(5.76)$ & $4(1.05)$ \\
8 & ICT makes course more interesting. & $173(45.29)$ & $181(47.38)$ & $5(6.54)$ & $3(0.79)$ \\
9 & ICT skill is worthwhile. & $184(48.16)$ & $164(42.93)$ & $1(8.12)$ & $3(0.79)$ \\
10 & ICT gives opportunity to learn more. & $155(40.58)$ & $172(45.02)$ & $8(9.94)$ & $17(4.45)$ \\
11 & I won't have anything to do with ICT. & $57(14.92)$ & $49(12.83)$ & $9(23.30)$ & $187(48.95)$ \\
12 & I have phobia for ICT equipment. & $60(15.71)$ & $93(24.35)$ & $08(28.27)$ & $121(31.66)$ \\
13 & ICT can't address the needs of school system. & $58(15.18)$ & $81(21.20)$ & $44(37.70)$ & $99(25.92)$ \\
14 & The state of facilities discourages me from & $90(23.56)$ & $125(32.72)$ & $06(27.75)$ & $61(15.9)$ \\
& using ICT & & & & \\
\hline
\end{tabular}


Based on the results in Table 2, there is every indication that responses to the positive statements (items $1-10$ ) show that over $50 \%$ of respondents have a positive attitude towards ICT. It is seen that more respondents believe that ICT could generally provide better learning experience. However, for negative statements (items $11-14$ ) show that only about $27.75 \%$ of the respondents agreed or strongly agreed that they won't have anything to do with ICT, while about $72.35 \%$ disagreed and also strongly disagreed on that statement. Item 12 shows that above $40.06 \%$ of respondents agreed that they have phobia for ICT equipment while about $59.04 \%$ of the respondents disagree that they have phobia for ICT equipments. Item 13 shows that about $63.62 \%$ of the respondents disagreed that ICT can't address the needs of school system, while the results on item 14 show that more than half of the respondents $(56.28 \%)$ agreed that the state of infrastructural facilities discourages them from using ICT. As seen from the analysis in Table 2, student-teachers generally have positive attitude towards ICT.

Research Question Two: What is the level of competence of student-teachers in the use of information and communication technology (ICT)?

The results in Table 3 are on student-teachers' competence in basic computer operation and understanding of ICT based issues.

Table 3. Analysis of Results on the Competence of Student-Teachers in Basic Computer Operation and Issues

\begin{tabular}{lllllll}
\hline S/N & Items & FC & RCU & OU & DU & NA \\
\cline { 1 - 2 } & $\begin{array}{l}\text { Basic Computer Operation and } \\
\text { Issues }\end{array}$ & & & & & \\
1 & $\begin{array}{l}\text { I can locate and run an } \\
\text { application program e.g. word }\end{array}$ & $152(39.79)$ & $93(24.35)$ & $98(25.64)$ & $20(5.24)$ & $13(3.40)$ \\
$2 \quad \begin{array}{l}\text { I can search for files on } \\
\text { computer system }\end{array}$ & $154(40.31)$ & $112(29.32)$ & $80(20.94)$ & $23(6.02)$ & $13(3.40)$ \\
$3 \quad \begin{array}{l}\text { I can connect the computer } \\
\text { and its peripherals }\end{array}$ & $113(29.58)$ & $107(28.01)$ & $95(24.87)$ & $43(11.26)$ & 24(6.28) \\
$4 \quad \begin{array}{l}\text { I can access information on } \\
\text { CD/DVD }\end{array}$ & $124(32.46)$ & $95(24.86)$ & $70(18.34)$ & $69(18.06)$ & $24(6.28)$ \\
5 & $\begin{array}{l}\text { I can organize electronic files } \\
\text { into folders }\end{array}$ & $87(22.77)$ & $72(18.85)$ & $74(19.37)$ & $106(27.75)$ & $43(11.26)$ \\
$6 \quad \begin{array}{l}\text { I can move files between } \\
\text { drives (e.g. from A: to C). }\end{array}$ & $100(26.18)$ & $71(18.57)$ & $83(21.73)$ & $92(24.08)$ & $36(9.42)$ \\
7 & $\begin{array}{l}\text { I can print to various } \\
\text { networked printers. }\end{array}$ & $102(26.70)$ & $74(19.37)$ & $87(22.77)$ & $85(22.25)$ & $34(8.90)$ \\
8 & $\begin{array}{l}\text { I am aware of computer } \\
\text { security, copyright and the }\end{array}$ & $124(32.46)$ & $90(23.56)$ & $62(16.23)$ & $56(14.56)$ & $50(13.09)$ \\
\hline $\begin{array}{l}\text { law. } \\
\text { I am aware of health and } \\
\text { safety issues relating to the } \\
\text { computing environment. }\end{array}$ & $131(34.29)$ & $95(24.87)$ & $61(15.97)$ & $45(11.78)$ & $50(13.09)$ \\
\hline
\end{tabular}


Most of the respondents indicated that they are competent on most of the items. For items 1 , $2,3,4,8$, and 9 , over 50 percent are fully competent or are regular and confident user of these applications/operations. Even, for items 5, 6, and 7 over 40 percent are fully competent or are regular and confident users of these applications/operations. It can also be observed that between 16 to 25 percents of the respondents noted that they had occasionally used these applications/operations but need further training.

The results in Table 4 are on student-teachers' competence in the use of application software. Results showed that the respondents indicated competency in the use of word processing package, items 10 and 11 (over 50 percent). However, for other items, 12 to 19, less than 40 percent are fully competent or are regular and confident users of spreadsheet, presentation, and database packages. Most of the respondents, over 25 percent indicated that they occasionally used these applications/operations but needed further training. These results underscore the need for the student-teachers to develop competency in the use of spreadsheet, presentation, and database packages applications.

Table 4. Analysis of Results on the Competence of Student-Teachers in the Use of Application Software

\begin{tabular}{|c|c|c|c|c|c|c|}
\hline$S / N$ & Items & FC & $\mathrm{RCU}$ & OU & $\mathrm{DU}$ & NA \\
\hline & Use of Application Software & & & & & \\
\hline 10 & $\begin{array}{l}\text { I can open a new document } \\
\text { in word }\end{array}$ & $156(40.83)$ & $88(23.04)$ & $85(22.35)$ & $39(10.21)$ & $14(3.66)$ \\
\hline 11 & $\begin{array}{l}\text { I can use simple editing e.g. } \\
\text { bold, italics, centering, font } \\
\text { size, etc. }\end{array}$ & $132(34.55)$ & $106(27.75)$ & $84(21.99)$ & $46(12.04)$ & 14(3.66) \\
\hline 12 & $\begin{array}{l}\text { I can use spreadsheet } \\
\text { package very well. }\end{array}$ & $70(18.32)$ & $84(21.99)$ & $104(27.23)$ & $102(26.70)$ & $22(5.76)$ \\
\hline 13 & $\begin{array}{l}\text { I can use spreadsheet to } \\
\text { make predictions. }\end{array}$ & $57(14.92)$ & $69(18.06)$ & $106(27.75)$ & 119(31.15) & $31(8.12)$ \\
\hline 14 & I can sort and filter data & $56(14.66)$ & $79(20.68)$ & $112(29.32)$ & $102(26.70)$ & $33(8.64)$ \\
\hline 15 & $\begin{array}{l}\text { I can create a basic } \\
\text { presentation package. }\end{array}$ & $69(18.06)$ & $72(18.85)$ & $102(26.7)$ & $105(27.5)$ & $34(8.9)$ \\
\hline 16 & $\begin{array}{l}\text { I can modify colors of text, } \\
\text { lines and spaces on a slide }\end{array}$ & 74(19.4) & $72(18.85)$ & $99(25.92)$ & $108(28.27)$ & $29(7.59)$ \\
\hline 17 & $\begin{array}{l}\text { I can introduce animation } \\
\text { into slides. }\end{array}$ & $31(8.12)$ & $71(18.59)$ & $120(31.41)$ & $87(22.77)$ & 73(19.11) \\
\hline 18 & I can set up a database & $52(13.61)$ & $78(20.42)$ & $101(26.44)$ & $116(30.37)$ & $35(9.16)$ \\
\hline 19 & $\begin{array}{l}\text { I can enter and update data } \\
\text { in a database. }\end{array}$ & $51(13.4)$ & $87(22.77)$ & $106(27.8)$ & $107(28.1)$ & $30(7.9)$ \\
\hline
\end{tabular}

On the respondents' use of Internet resources, Table 5 shows that they are competent in most of the items. For instance, over 50 percent of them noted that they are fully competent or a regular and confident users of the resources in items $(20,21,22,23,24,26,27,28$ and 31), while over 47 percent indicated that they can save a document in various file formats including HTML (item 25). However, for item 29, only 41.09 percent indicated that they are fully competent or are regular and confident users of deep web searching using meta-search engines, while for item 30, 45.02 percent are fully competent or are regular and confident 
users of web authoring tools. In addition, between 15.96 percent (item 31) and 22.77 percent (items 25 and 30) noted that they occasionally used these applications/operations but needed further training for Internet resources.

Table 5. Results on the Competence of Student-Teachers in the Use of Internet Resources

\begin{tabular}{|c|c|c|c|c|c|c|}
\hline $\mathrm{S} / \mathrm{N}$ & Items & FC & RCU & OU & DU & NA \\
\hline & Use of the Internet Resources & & & & & \\
\hline 20 & $\begin{array}{l}\text { I can access an Internet site } \\
\text { via its website address. }\end{array}$ & $146(38.22)$ & $112(29.32)$ & $69(18.06)$ & $38(9.95)$ & $17(4.45)$ \\
\hline 21 & $\begin{array}{l}\text { I can download files from the } \\
\text { Internet. }\end{array}$ & $134(34.45)$ & $115(30.10)$ & $72(18.85)$ & $35(9.16)$ & $26(6.81)$ \\
\hline 22 & $\begin{array}{l}\text { I can send and receive e-mail } \\
\text { messages. }\end{array}$ & $156(40.84)$ & $109(28.54)$ & $68(17.80)$ & $33(8.64)$ & $16(4.19)$ \\
\hline 23 & $\begin{array}{l}\text { I can attach files to outgoing } \\
\text { e-mails. }\end{array}$ & $117(30.6)$ & $99(25.92)$ & $80(20.94)$ & $61(15.97)$ & $25(6.54)$ \\
\hline 24 & $\begin{array}{l}\text { I can sort messages and file in } \\
\text { created folders }\end{array}$ & $117(30.63)$ & $87(22.77)$ & $84(21.99)$ & $72(18.85)$ & $22(5.76)$ \\
\hline 25 & $\begin{array}{l}\text { I can save a document in } \\
\text { various file formats including } \\
\text { HTML. }\end{array}$ & $96(25.13)$ & $87(22.77)$ & $87(22.77)$ & $72(18.85)$ & $40(10.47)$ \\
\hline 26 & $\begin{array}{l}\text { I can save text and images } \\
\text { from web pages. }\end{array}$ & $102(26.70)$ & $94(24.61)$ & $71(18.59)$ & $82(21.47)$ & $33(8.64)$ \\
\hline 27 & $\begin{array}{l}\text { I can communicate online } \\
\text { with other students on } \\
\text { homework / assignment. }\end{array}$ & $136(35.60)$ & $93(24.35)$ & $75(19.63)$ & $57(14.92)$ & $21(5.50)$ \\
\hline 28 & $\begin{array}{l}\text { I can use web search engines } \\
\text { (google, alltheweb, altavista, } \\
\text { etc) very well. }\end{array}$ & $132(34.55)$ & $103(26.96)$ & $63(16.49)$ & $60(15.71)$ & $24(6.28)$ \\
\hline 29 & $\begin{array}{l}\text { I can do deep web searching } \\
\text { using appropriate meta- } \\
\text { search engines (Surf Wax, } \\
\text { Vivissimo, HotBot, etc.) very } \\
\text { well. }\end{array}$ & $75(19.63)$ & $82(21.47)$ & $86(22.51)$ & $104(27.23)$ & $35(9.16)$ \\
\hline 30 & I can use web authoring tools. & $97(25.39)$ & 75(19.63) & $87(22.77)$ & 102(26.70) & $41(10.70)$ \\
\hline 31 & $\begin{array}{l}\text { I can chat on the Internet } \\
\text { using instant messaging tools } \\
\text { (Yahoo, MSN, Skype, etc.) }\end{array}$ & $135(35.34)$ & $85(22.25)$ & $61(15.96)$ & $70(18.32)$ & $31(8.12)$ \\
\hline
\end{tabular}

The results in Table 6 are on student-teachers' competence in the use peripheral ICT equipment. From the results less than 45 percent of the respondents had competency in the use of digital camera, web camera, and liquid crystal display projector. However, for item 35 on use of scanner 46.85 percent of the respondents are fully competent or a regular and confident users. In addition, between 18.32 and 24.87 percents indicated that they occasionally used these equipment but needed further training. 
Table 6. Results on the Competence of Student-Teachers in the Use of Peripheral ICT Equipment

\begin{tabular}{|c|c|c|c|c|c|c|}
\hline$S / N$ & Items & FC & $\mathrm{RCU}$ & OU & DU & NA \\
\hline & $\begin{array}{l}\text { Use of Peripheral ICT } \\
\text { Equipment }\end{array}$ & & & & & \\
\hline 32 & $\begin{array}{l}\text { I can use a digital camera to } \\
\text { capture images. }\end{array}$ & $86(22.51)$ & $68(17.80)$ & $95(24.87)$ & $95(24.87)$ & $38(9.95)$ \\
\hline 33 & $\begin{array}{l}\text { I can use the web camera to } \\
\text { communicate on the Internet }\end{array}$ & $84(21.99)$ & $51(13.35)$ & $90(23.56)$ & $117(30.63)$ & $40(10.47)$ \\
\hline 34 & $\begin{array}{l}\text { I can set up and use Liquid } \\
\text { Crystal Display (LCD) or } \\
\text { Multimedia Projector }\end{array}$ & $49(12.83)$ & $74(19.37)$ & $70(18.32)$ & $137(35.34)$ & $52(13.61)$ \\
\hline 35 & $\begin{array}{l}\text { I can use a scanner to copy } \\
\text { images. }\end{array}$ & $101(26.44)$ & $78(20.42)$ & $82(21.47)$ & $87(22.77)$ & $34(8.90)$ \\
\hline
\end{tabular}

Based on the responses of the student-teachers on their competence in the use of ICT, further information was elicited on where they acquired ICT knowledge and skills, and their perception on the importance of ICT in their future career. The results are presented in Tables 7 and 8.

Table 7. Percentages on Where Student-Teachers Learnt ICT Knowledge and Skills

\begin{tabular}{|c|c|c|c|c|c|c|c|c|c|c|c|}
\hline Variables & & $\begin{array}{l}\text { Spe } \\
\text { Cou } \\
\text { for }\end{array}$ & & $\begin{array}{l}\text { Cours } \\
\text { Unive }\end{array}$ & $\begin{array}{l}\text { by } \\
\text { sity }\end{array}$ & $\begin{array}{l}\text { Tau } \\
\text { frie } \\
\text { fam }\end{array}$ & $\begin{array}{l}\text { ght by } \\
\text { dds or } \\
\text { ily }\end{array}$ & & $\begin{array}{l}\text { Self } \\
\text { taught }\end{array}$ & & $\begin{array}{l}\text { Course } \\
\text { Outside } \\
\text { University }\end{array}$ \\
\hline \multirow{3}{*}{ Gender } & \multirow{3}{*}{$\begin{array}{l}\text { Male } \\
\text { Female }\end{array}$} & $\mathrm{N}$ & $\%$ & $\mathrm{~N}$ & $\%$ & $\mathrm{~N}$ & $\%$ & $\mathrm{~N}$ & $\%$ & $\mathrm{~N}$ & $\%$ \\
\hline & & 48 & 26.52 & 27 & 14.92 & 40 & 22.1 & 37 & 20.44 & 29 & 16.02 \\
\hline & & 70 & 38.31 & 20 & 9.95 & 56 & 27.86 & 34 & 16.92 & 21 & 10.45 \\
\hline \multirow{5}{*}{ Departments } & ASSE & 34 & 33.33 & 14 & 13.73 & 26 & 25.49 & 14 & 13.73 & 14 & 13.73 \\
\hline & CED & \multirow{2}{*}{$\begin{array}{l}14 \\
28\end{array}$} & \multirow{2}{*}{$\begin{array}{l}37.83 \\
33.33\end{array}$} & 6 & 16.22 & 10 & 27.03 & 3 & 8.11 & 4 & 10.81 \\
\hline & EDM & & & 9 & 10.71 & 13 & 15.48 & 20 & 23.81 & 14 & 16.67 \\
\hline & HKHE & 15 & 27.78 & 5 & 9.26 & 16 & 29.63 & 12 & 22.22 & 6 & 11.11 \\
\hline & SED & 27 & 25.71 & 13 & 12.38 & 31 & 29.52 & 22 & 20.95 & 12 & 11.43 \\
\hline
\end{tabular}

The results in Table 7 indicate where the student-teachers had their ICT knowledge and competences. As reflected in the table majority of the student-teachers had their knowledge and skills outside the University course system or training programmes. Over 50 percent of the male and female students were taught by friends or family members (Male $22.10 \%$ and $27.86 \%$ ), self taught (male $20.44 \%$ and female $16.92 \%$ ), or acquired through a course outside the University system (male $16.02 \%$ and female 10.45\%). Similar trend could be observed for students across departments, except for the Department of Counsellor where over 50 percent indicated that they had the knowledge and skills within the University, that is, 37.83 and 16.22 percents for special course for ICT and course by the University, respectively.

These findings indicate that most student-teachers have acquired their ICT competences independent of the University. This stems from the fact that no specific course is available in the Nigerian teacher education programs on ICT. The Approved Minimum Academic Standard (AMAS) which had been in operation in Nigerian universities only recommends a minimum of 
2-credit course in educational technology, a course that accommodates several contents with ICT related aspect being treated within two or three hours in a semester. Specific ICT related courses are, in most cases, elective for student-teachers. The draft review of the AMAS document, which is expected to take off in Nigerian universities, however, has elements which accommodate learning about ICT integration in teacher education.

In addition, student-teachers were asked to indicate their perception of the importance of ICT in their future career, and the results of the analysis are as shown in Table 8.

Table 8. Percentages on Student-Teachers Perception of ICT Skills in Future Career

\begin{tabular}{|c|c|c|c|c|c|c|c|c|c|}
\hline \multicolumn{2}{|l|}{ Variables } & \multicolumn{2}{|c|}{$\begin{array}{l}\text { Very } \\
\text { important }\end{array}$} & \multicolumn{2}{|c|}{ Important } & \multicolumn{2}{|c|}{$\begin{array}{l}\text { Of } \\
\text { some } \\
\text { value }\end{array}$} & \multicolumn{2}{|c|}{$\begin{array}{l}\text { Little or no } \\
\text { importance }\end{array}$} \\
\hline \multirow{3}{*}{ Gender } & \multirow{3}{*}{$\begin{array}{l}\text { Male } \\
\text { Female }\end{array}$} & $\mathrm{N}$ & $\%$ & $\mathrm{~N}$ & $\%$ & $\mathrm{~N}$ & $\%$ & $\mathrm{~N}$ & $\%$ \\
\hline & & 109 & 60.22 & 59 & 32.60 & 4 & 2.21 & 9 & 4.97 \\
\hline & & 108 & 53.73 & 67 & 33.33 & 10 & 4.98 & 16 & 7.96 \\
\hline \multirow{5}{*}{ Departments } & ASSE & 46 & 45.10 & 41 & 40.19 & 5 & 4.90 & 10 & 0.98 \\
\hline & CED & 20 & 54.04 & 14 & 37.84 & 2 & 5.41 & 1 & 2.70 \\
\hline & EDM & 50 & 59.52 & 28 & 33.33 & 2 & 2.38 & 4 & 4.76 \\
\hline & HKHE & 29 & 53.70 & 16 & 29.63 & 1 & 1.85 & 8 & 14.81 \\
\hline & SED & 72 & 68.57 & 27 & 25.71 & 4 & 3.81 & 2 & 1.90 \\
\hline
\end{tabular}

As shown in Table 8, over 80 percents of the sampled students indicated that ICT will be very important or important for their future career as teachers, irrespective of gender or department. The recognition of the importance of the role of ICT in their future career explains their acquisition of basic ICT competences and knowledge, even when their teacher education programmes place less importance on ICT.

Hypothesis One: There is no significant difference between the attitude of male and that of female student-teachers towards information and communication technology.

The results of the chi-square analysis for the 14 items on attitude are as reflected in Table 9. From the table it is seen that there is no significant difference in the attitude of male and that of female student-teachers' towards ICT as can be observed from the results on all the items. The chi-square analysis shows that there is no significant difference between the attitude of male and that of female student-teachers' toward ICT, therefore, the null hypothesis is accepted. 
Table 9. Chi-Square Analysis on Male and Female Student-Teachers' Attitude towards ICT

\begin{tabular}{|c|c|c|c|c|c|c|}
\hline \multirow[t]{2}{*}{$\mathrm{S} / \mathrm{N}$} & \multirow[t]{2}{*}{ Items } & \multicolumn{2}{|c|}{ Mean Values } & \multirow[b]{2}{*}{$\begin{array}{l}\text { Chi- } \\
\text { Squ } \\
\text { are }\end{array}$} & \multirow[b]{2}{*}{ df } & \multirow[b]{2}{*}{$\begin{array}{l}\text { Asy } \\
\text { mp. } \\
\text { Sig. }\end{array}$} \\
\hline & & Male & Female & & & \\
\hline 1 & ICT enhances students' learning. & 3.68 & 3.75 & 3.09 & 3 & 0.38 \\
\hline 2 & Teacher education should include ICT. & 3.70 & 3.56 & 3.49 & 3 & 0.32 \\
\hline 3 & $\begin{array}{l}\text { Mail creates more information between teachers } \\
\text { and learners. }\end{array}$ & 3.25 & 3.29 & 2.57 & 3 & 0.46 \\
\hline 4 & ICT provides better learning experiences. & 3.49 & 3.53 & 0.52 & 3 & 0.92 \\
\hline 5 & I would work harder if I could use ICT. & 3.23 & 3.22 & 1.50 & 3 & 0.68 \\
\hline 6 & I learn more from ICT than I do from books. & 3.12 & 3.13 & 0.26 & 3 & 0.97 \\
\hline 7 & ICT is useful in dissemination of information. & 3.39 & 3.41 & 5.56 & 3 & 0.14 \\
\hline 8 & ICT makes course more interesting. & 3.40 & 3.35 & 1.65 & 3 & 0.65 \\
\hline 9 & ICT skill is worthwhile. & 3.43 & 3.34 & 4.06 & 3 & 0.26 \\
\hline 10 & ICT gives opportunity to learn more. & 3.25 & 3.19 & 3.07 & 3 & 0.38 \\
\hline 11 & I won't have anything to do with ICT. & 1.91 & 1.96 & 0.53 & 3 & 0.91 \\
\hline 12 & I have phobia for ICT equipment. & 2.28 & 2.20 & 0.56 & 3 & 0.91 \\
\hline 13 & ICT can't address the needs of school system. & 2.24 & 2.27 & 6.77 & 3 & 0.08 \\
\hline 14 & $\begin{array}{l}\text { The state of facilities discourages me from using } \\
\text { ICT }\end{array}$ & 2.64 & 2.65 & 5.33 & 3 & 0.15 \\
\hline
\end{tabular}

Hypothesis Two: There is no significant difference in the competence of male and that of female student-teachers' in the use of information and communication technology (ICT).

Table 10. Chi-Square Analysis on Male and Female Competence in Basic Computer Operation and Issues

\begin{tabular}{|c|c|c|c|c|c|c|}
\hline & \multicolumn{6}{|c|}{ Mean Values } \\
\hline \multicolumn{2}{|r|}{ Items } & Male & Female & $\begin{array}{c}\text { Chi- } \\
\text { Square }\end{array}$ & $\mathrm{df}$ & $\begin{array}{l}\text { Asymp. } \\
\text { Sig. }\end{array}$ \\
\hline & \multicolumn{6}{|l|}{ Basic Computer Operation and Issues } \\
\hline 1 & $\begin{array}{l}\text { I can locate and run an application program e.g. } \\
\text { word }\end{array}$ & 2.97 & 2.84 & 2.26 & 4 & 0.69 \\
\hline 2 & I can search for files on computer system & 3.00 & 2.95 & 1.67 & 4 & 0.80 \\
\hline 3 & I can connect the computer and its peripherals & 2.67 & 2.60 & 1.02 & 4 & 0.91 \\
\hline 4 & I can access information on CD/DVD & 2.73 & 2.47 & 5.25 & 4 & 0.26 \\
\hline 5 & I can organize electronic files into folders & 2.23 & 2.06 & 2.37 & 4 & 0.67 \\
\hline 6 & I can move files between drives (e.g. from A: to C). & 2.43 & 2.14 & 7.22 & 4 & 0.13 \\
\hline 7 & I can print to various networked printers. & 2.46 & 2.21 & 11.91 & 4 & $0.02 *$ \\
\hline 8 & $\begin{array}{l}\text { I am aware of computer security, copyright and the } \\
\text { law. }\end{array}$ & 2.58 & 2.38 & 14.43 & 4 & $0.01 *$ \\
\hline 9 & $\begin{array}{l}\text { I am aware of health and safety issues relating to the } \\
\text { computing environment. }\end{array}$ & 2.57 & 2.57 & 2.55 & 4 & 0.64 \\
\hline
\end{tabular}

* Significant at 0.05 level. 
From the results in Table 10 no significant difference was established between the competence of male and that of female in seven out of the nine items. However, significant differences were established in two of the items ( 7 and 8 ) in favor of male student-teachers who had higher mean values of 2.46 and 2.58 , respectively, rather than in female studentteachers who had 2.21 and 2.38, respectively. Overall, it can be deduced that no significant difference was established between the competence of male and that of female studentteachers in the use of ICT, thus the null hypothesis was accepted.

Table 11. Chi-Square Analysis on Male and Female Competence in the Use of Application Software

\begin{tabular}{|c|c|c|c|c|c|c|}
\hline & \multirow[b]{2}{*}{ Items } & \multicolumn{5}{|c|}{ Mean Values } \\
\hline & & Male & Female & $\begin{array}{l}\text { Chi- } \\
\text { Square }\end{array}$ & $\mathrm{df}$ & $\begin{array}{l}\text { Asymp. } \\
\text { Sig. }\end{array}$ \\
\hline & \multicolumn{6}{|l|}{ Use of Application Software } \\
\hline 10 & I can open a new document in word & 2.90 & 2.85 & 0.97 & 4 & 0.92 \\
\hline 11 & $\begin{array}{l}\text { I can use simple editing e.g. bold, italics, } \\
\text { centering, font size, etc }\end{array}$ & 2.83 & 2.72 & 1.09 & 4 & 0.90 \\
\hline 12 & I can use spreadsheet package very well. & 2.20 & 2.20 & 2.46 & 4 & 0.65 \\
\hline 13 & I can use spreadsheet to make predictions. & 1.94 & 2.06 & 2.68 & 4 & 0.61 \\
\hline 14 & I can sort and filter data & 2.00 & 2.11 & 4.16 & 4 & 0.39 \\
\hline 15 & I can create a basic presentation package. & 2.08 & 2.11 & 6.70 & 4 & 0.15 \\
\hline 16 & $\begin{array}{l}\text { I can modify colors of text, lines and spaces on } \\
\text { a slide }\end{array}$ & 2.51 & 2.31 & 8.07 & 4 & 0.09 \\
\hline 17 & I can introduce animation into slides. & 2.49 & 2.37 & 6.15 & 4 & 0.19 \\
\hline 18 & I can set up a database & 1.91 & 2.06 & 3.28 & 4 & 0.51 \\
\hline 19 & I can enter and update data in a database. & 2.01 & 2.10 & 6.80 & 4 & 0.15 \\
\hline
\end{tabular}

When the hypothesis was tested on the use of generic software the results in Table 11 indicated that there is no significant difference between the competence of male and that of female in all the items. Therefore, the null which states that no difference exists in the competence of male and female student-teachers in the use of ICT (use of software) was accepted.

From the results in Table 12, no significant difference was established between the competence of male and that of female in eight out of the twelve items. However, significant differences were established in four of the items $(23,24,36$ and 31) more in favor of male student-teachers who had higher mean values of 2.56 and 2.59, 2.60, and 2.75, respectively, than in female student-teachers who had 2.20 and 2.30, 2.21, and 2.44, respectively. Generally, it can be inferred that no significant difference was established between the competence of male and that of female student-teachers in the use of ICT (Internet resources), thus the null hypothesis was accepted. 
Table 12. Chi-Square Analysis on Male and Female Competence in the Use of Internet Resources

\begin{tabular}{|c|c|c|c|c|c|c|}
\hline & \multirow[b]{2}{*}{ Items } & \multicolumn{2}{|c|}{ Mean Values } & \multirow[b]{2}{*}{$\begin{array}{l}\text { Chi- } \\
\text { Square }\end{array}$} & \multirow[b]{2}{*}{ df } & \multirow[b]{2}{*}{$\begin{array}{l}\text { Asymp. } \\
\text { Sig. }\end{array}$} \\
\hline & & Male & Female & & & \\
\hline & Use of the Internet Resources & & & & & \\
\hline 20 & $\begin{array}{l}\text { I can access an Internet site via its website } \\
\text { address. }\end{array}$ & 2.98 & 2.77 & 5.11 & 4 & 0.28 \\
\hline 21 & I can download files from the Internet. & 2.94 & 2.63 & 7.39 & 4 & 0.11 \\
\hline 22 & I can send and receive e-mail messages. & 2.99 & 2.88 & 5.26 & 4 & 0.26 \\
\hline 23 & I can attach files to outgoing e-mails. & 2.56 & 2.20 & 13.58 & 4 & $0.01^{*}$ \\
\hline 24 & I can sort messages and file in created folders & 2.59 & 2.30 & 10.17 & 4 & $0.04 *$ \\
\hline 25 & $\begin{array}{l}\text { I can save a document in various file formats } \\
\text { including HTML. }\end{array}$ & 2.22 & 2.08 & 4.08 & 4 & 0.40 \\
\hline 26 & I can save text and images from web pages. & 2.60 & 2.21 & 20.53 & 4 & $0.00^{*}$ \\
\hline 27 & $\begin{array}{l}\text { I can communicate online with other students on } \\
\text { homework / assignment. }\end{array}$ & 2.82 & 2.59 & 5.47 & 4 & 0.24 \\
\hline 28 & $\begin{array}{l}\text { I can use web search engines (google, alltheweb, } \\
\text { altavista, etc) very well. }\end{array}$ & 2.77 & 2.60 & 2.45 & 4 & 0.65 \\
\hline 29 & $\begin{array}{l}\text { I can do deep web searching using appropriate } \\
\text { meta-search engines (Surf Wax, Vivissimo, } \\
\text { HotBot, etc.) very well }\end{array}$ & 2.22 & 2.09 & 3.72 & 4 & 0.45 \\
\hline 30 & I can use web authoring tools. & 2.17 & 2.07 & 4.77 & 4 & 0.31 \\
\hline 31 & $\begin{array}{l}\text { I can chat on the Internet using instant messaging } \\
\text { tools (Yahoo, MSN, Skype, etc.) }\end{array}$ & 2.75 & 2.44 & 13.40 & 4 & $0.01^{*}$ \\
\hline
\end{tabular}

* Significant at 0.05 level.

Table 13. Chi-Square Analysis on Male and Female 'Student-Teachers' Competence in the Use of Peripheral ICT Equipment

\begin{tabular}{|c|c|c|c|c|c|c|}
\hline \multicolumn{7}{|c|}{ Mean Values } \\
\hline \multicolumn{2}{|c|}{ Items } & \multirow[t]{2}{*}{ Male } & \multirow[t]{2}{*}{ Female } & \multirow[t]{2}{*}{$\begin{array}{l}\text { Chi- } \\
\text { Square } \\
\end{array}$} & \multirow[t]{2}{*}{$\mathrm{df}$} & \multirow[t]{2}{*}{$\begin{array}{l}\text { Asymp. } \\
\text { Sig. }\end{array}$} \\
\hline & Use of Peripheral ICT Equipment & & & & & \\
\hline 32 & $\begin{array}{l}\text { I can use a digital camera to capture } \\
\text { images. }\end{array}$ & 2.23 & 2.14 & 3.78 & 4 & 0.44 \\
\hline 33 & $\begin{array}{l}\text { I can use the web camera to } \\
\text { communicate on the Internet }\end{array}$ & 2.23 & 1.90 & 11.50 & 4 & $0.02 *$ \\
\hline 34 & $\begin{array}{l}\text { I can set up and use Liquid Crystal Display } \\
\text { (LCD) or Multimedia Projector }\end{array}$ & 1.79 & 1.85 & 6.03 & 4 & 0.20 \\
\hline 35 & I can use a scanner to copy images. & 2.36 & 2.29 & 1.48 & 4 & 0.83 \\
\hline
\end{tabular}

* Significant at 0.05 level.

As seen from the results in Table 13 no significant difference was established between the competence of male and that of female student-teachers in three out of the four items. 
However, significant differences were established in item 33 in favor of male student-teachers who had higher mean values of 2.23 than in female student-teachers who had 1.90 . Generally, it can be inferred that no significant difference was established between the competence of male and that of female student-teachers in the use of peripheral ICT equipment, thus the null hypothesis was accepted.

\section{Discussion}

The potentials of information and communication technology (ICT) as an educational tool in teacher education had been well established by several studies. This study investigated the competence and attitude of student-teachers towards information and communication technology at the University of Ilorin, Ilorin, Nigeria. Results from the self-report used for this present study revealed that student-teachers at the University of Ilorin seem to have positive attitude comparable to that of student-teachers in other countries (Kennewell \& Morgan, 2003, Chai, Hong, Huang-Yao, \& Teo, 2008). This positive attitude is an important indicator of willingness and first step in effective ICT integration in curriculum. This study also revealed no significant gender difference in their attitude towards ICT.

The results further indicated that majority of the student-teachers lack skills in various ICT applications and equipment operations that are important to support and enhance their learning experiences and ICT integration in instruction. Majority of student-teachers (over $50 \%$ ) at the University of Ilorin are not competent in the use of spreadsheet, presentation, database, and web authoring tools; and also the use of peripheral ICT equipment. Generally, this study revealed no significant difference between male and female student-teachers in their competence in the use of ICT. However, significant differences were established in seven out of 35 items on ICT competence. In addition, male student-teacher had higher mean scores for almost all the items on basic ICT competence. This finding is consistent with the findings of previous studies that showed that male students are likely to be more competent than female students are in the use of ICT (Derbyshire, 2003). But, the overall no significant difference is consistent with conclusions of Kirkpatrick and Cuban (1998).

Further exploration of how student-teachers gained their competency in the use of ICT revealed that majority of the students (more than 60\%) gained their ICT competence through personal study, family or friends and through training outside the university. This finding implies that the ICT training provided by the university for the student-teachers do not meet the needs for them to integrate ICT in their teaching. This underscores the need for more emphasis to be placed on exposing student-teachers to advanced courses in ICT. Nigerian universities, indeed, universities in the developing nation would need to improve on their ICT content in line with the UNESCO $(2008 a, 2008 b)$ ICT competency standards for teachers.

The University's administration emphasis on integrating ICT since year 2008 should be implemented within defined educational strategy. Students should be exposed to computerassisted learning (CAL) in teacher education to promote self-directed learning, and thus bring student-teachers up to an acceptable level of competency in the use of ICT. In addition, computer-based test currently used for large classes should be expanded to cover most courses. In addition, online teaching should be explored to allow students to focus more on managing their own learning and to work at their own time and pace; and this will also allow the use of sound, videos, and animation to communicate information (Rajab \& Baqain, 2005). 


\section{Limitations of the Study}

The questionnaire, a self-report, was used to gather data. The overall approach would have been strengthened by the use of classroom observation, interviews, and focus-groups. Observation would have been relevant in gathering data on student-teachers ICT skills and actual use of ICT. Focus group would have been good for identifying and exploring pre-service teachers' views in-depth about ICT provision and their construction of meaning. Another major weakness is the fact that the sample included only student-teachers who happened to be in class on the days when the questionnaire copies were administered. Furthermore, there was imbalance in the sub-sample based on departments although most reflect enrolment for programs. Despite these limitations, in the view of the authors, the gains for the research far outweigh the limitations.

\section{Conclusions}

In this study, it was discovered that student-teachers have positive attitude towards the use of ICT. The results revealed that among the basic computer competency sub-divisions, studentteachers indicated competency in general computer operation, word processing, downloading and using basic internet resources. However, the same students lacked required competence in the use of spreadsheet, presentation, database, and web authoring tools; and also the use of peripheral ICT equipment. The findings underscore the need to introduce student-teachers to more courses on ICT with needed hand-on experiences so as to promote effective integration of ICT throughout the curriculum by student-teachers. In addition, it brings to the fore the need for teacher educators to model good use of ICT in their instruction.

Gender had no significant influence on the attitude of student-teachers towards ICT, and similarly no significant difference was established between male and female student-teachers in their ICT competence. Furthermore, existing courses were found to be inadequate to facilitate student-teachers acquisition of necessary ICT related skills so that they can be competent teachers integrating technology in instruction. Thus, it was also discovered that most of the respondents learned their current ICT skills and knowledge of computer programs outside the university.

One of the problems facing the development of ICT in schools include the fact that there is limited infrastructural facilities, difficulties in infusing Internet use into the curriculum and also lack of appropriate teacher development. It is very important that these problems are addressed since it is the student-teachers that would produce highly placed citizens in future. Also, provisions should be made for lecturers to be able to integrate ICT-based methodology into their lectures, and also, all classrooms should be equipped with necessary infrastructure and, lastly, all students should be provided with access to media laboratories whenever they want to.

It may be necessary for further research to be conducted on the impact of the online registration, computer-based test, the Microsoft digital literacy programme etc. on students' ICT competency, and other innovative application of ICT in Nigerian universities and other universities in the developing nations. This study has established the wide gap between the UNESCO's ICT competency standards for teachers and what is obtained in teacher education. 


\section{References}

Ajzen, I. \& Fishbein, M. (1980) Understanding attitudes and predicting social behavior. Englewood Cliffs, NJ: Prentice- Hall.

Bebetsos, E. \& Antoniou, P. (2008 October). University students' differences on attitudes towards computer use. Comparison with students' attitudes towards physical activity. Interactive Educational Multimedia, 17, 20-28. Retrieved 3 February 2009 from http://greav.ub.edu/iem/index.php?journal=iem\&page=article\&op=view\&path[]=130\&p ath[] $=198$

Chai, C. S., Hong, H., \& Teo, T. (2008, October). Singaporean and Taiwanese pre-service teachers' beliefs and their attitude towards ICT: A comparative study. Paper presented at the 16th International Conference on Computers in Education. Retrieved from http://www.apsce.net/icce2008/papers/ICCE2008-paper19.pdf

Collis, B. \& Monnen, J. (2001). Flexible learning in a digital world: Experiences and expectations. London: Kogan Page.

Derbyshire, H. (2003). Gender issues in the use of computers in education in Africa. Retrieved 25 January 2008 from http://imfundo.digitalbrain.com/imfundo/web/learn/documents/ Gender\%20Report.pdf

Dyck, J. L. \& Smither, J. A. (1995). Older adults' acquisition of word processing. The contribution of cognitive abilities and computer anxiety. Computer in Human Behavior, $12(1), 107-199$.

Idowu, B., Ogunbodede, E., \& Idowu, B. (2003). Information and communication technology in Nigeria: The health sector experience. Journal of Information Technology Impact, 3 (2), 69-76.

Jackson, L. A., Ervin, K. S., Gardner, P. D., \& Schmitt, N. (2001). Gender and the internet. Women communication and men searching. Sex Roles, 44 (5), 363-379.

Jegede, P. O. (2008). Attitudinal characteristics and use level of Nigerian teachers. Issues in Informing Science and Information Technology, 5. Retrieved 15 December 2008 from http://proceedings.informingscience.org/InSITE2008/IISITv5p261-266Jegede533.pdf

Jegede, P. O. \& Owolabi, J. A. (2003). Computer education in Nigerian secondary schools. Gaps between policy and practice. Meridian 6 (2). Retrieved 23 November 2004 from http://www.ncsu.edu/meridian/sum2003/nigeria/index.html

Kadel, R. (2005, February). How teacher attitude affect technology. Learning and Leading with Technology, 39 (5), 34-47.

Kazu, I. Y. \& Yavulzalp, N. (2008). An analysis of the primary school teachers' usage of instructional software. International Journal of Emerging Technologies, 3 (1), 45-53.

Kennewell, S. \& Morgan, A. (2003, July). Student teachers' experiences and attitudes towards using interactive whiteboards in the teaching and learning of young children. Presented at the IFIP Working Groups 3.5 Conference: Young Children and Learning Technologies. UWS Parramatta. Retrieved 16 July 2007 from http://crpit.com/confpapers/ CRPITV34Kennewell1.pdf

Khine, M. S. (2001). Attitudes toward computers among teacher education students in Brunei Darussalam. International Journal of Instructional Media, 28 (2), 147-153. 
Kirkpatrick, H. \& Cuban, L (1998). Should we be worried? What the research says about gender differences in access, use, attitudes, and achievements with computer. Educational Technology, 38 (4), 56-60.

Kirschner, P. \& Woperies, I. G. J. H. (2003). Pedagogic benchmarks for information and communication technology in teacher education. Technology, Pedagogy and Education, 12 (1), 127-149.

Kumar, P. \& Kumar A. (2003). Effect of a web-based project on preservice and inservice teachers' attitudes toward computers and technology skills. Journal of Computing in Teacher Education, 19(3), 87-92.

Kyriakidou, M., Chrisostomou, C., \& Bank, F. (2000, September). Primary teachers' attitude to the use of ICT: A comparative study between Cyprus and the UK. Paper presented at the European Conference on Educational Research. Lahti, Finland.

Lee, D. (1997). Factors influencing the success of computer skills learning among in-service teachers. British Journal of Educational Technology, 28, 139-141.

Marija, B. \& Palmira, P. (2007). Would-Be Teachers' Competence in Applying ICT: Exposition and Preconditions for Development. Informatics in Education - An International Journal, 6(2), 397-410.

Moursund, D. \& Bielefeldt, T. (1999). Will new teachers be prepared to teach in a digital age? Santa Monica. Milken Family Foundation.

Ololube, N. P. (2007). The relationship between funding, ICT, selection processes, administration, planning and the standard of science teacher education in Nigeria. AsiaPacific Forum on Science Learning and Teaching, 8(1). Retrieved 15 December 152008 from http://www.ied.edu.hk/apfslt/v8_issue1/ololube/index.htm\#abstract

Rajab, L. D. \& Baqain, Z. H., (2005). Use of information and communication technology among dental students at the University of Jordan. Journal of Dental Education, 69(3), 387-398.

Robbins, V. (1998). The development of information technology skills in trainee teachers for further education sector. Research in Post-Compulsory Education, 3 (2), 240-251.

Schaumburg, H. (2001). Fostering girls' computer through laptop learning - Can mobile computers help to level out the gender difference? Retrieved 17 July 2008 from http://www.notesys.com/Copies/necc01.pdf

Sefyrin, J. (2005, July). Understandings of gender and competence in ICT. Paper presented at 6 th International Women into Computing Conference. University of Greenwich. Retrieved 12 April 2008 from http://www.miun.se/upload/Institutioner/ITM/IKS/ SI/publikationer/sefyrin_WiC.pdf

Teo, T. (2008). Pre-service teachers' attitude towards computer use: A Singapore survey. Australian Journal of Educational Technology, 23(4), 413-424.

Townsend, M. (1997). Computer block - does it exist in the comprehensive secondary schools? British Journal of Educational Technology, 28, 219-221.

United Nations Educational, Scientific and Cultural Organization (2008a). ICT competency standards for teachers: Policy framework. United Kingdom: Author. Retrieved 23 January 2009 from http://www.oei.es/tic/competencias_tic_docentes_marcos_politicas.pdf

United Nations Educational, Scientific and Cultural Organization (2008b). ICT competency standards for teachers: Implementation guidelines (Version 1.0). United Kingdom: 
Author. Retrieved 23 January 2009 from http://unesdoc.unesco.org/images/0015/ 001562/156209E.pdf

Yuen, H. K. \& Ma, W. K. (2002). Gender differences in teacher computer acceptance. Journal of Technology and Teacher Education, 10 (3), 365-382.

Yusuf, M. O. (1998) A study of the dimensions of teachers' attitude towards computer education in Nigerian secondary schools. Journal of Computer Literacy, 2(1), 47-58.

Yusuf, M O. (2005). An investigation into teachers' self-efficacy in implementing computer education in Nigerian secondary schools. Meridian: A Middle School Computer Technologies Journal, 8 (2).

Zammit, S. A. (1992). Factors facilitating or hindering the use of computers in schools. Educational Research, 34, 57-66.

Correspondence: Mudasiro O. Yusuf, Associate Professor of Educational Technology, Department of Science Education, Faculty of Education, University of Ilorin, Kwara State, Nigeria. 